\title{
Taxithelium juruense (Broth.) Broth. (Pylaisiadelphaceae) an endangered Brazilian endemic, with notes on the genus Taxithelium in Brazil
}

Paulo Eduardo Aguiar Saraiva Câmara ${ }^{1,2}$ and Micheline Carvalho-Silva ${ }^{1}$

Recebido em 28/09/2010. Aceito em 14/02/2011

\begin{abstract}
RESUMO
(Taxithelium juruense (Broth.) Broth.(Pylaisiadelphaceae), uma espécie brasileira ameaçada e notas sobre o gênero Taxithelium no Brasil). Desde a sua descrição original diversas coletas têm sido reportadas para este táxon em diferentes estados brasileiros. Durante a revisão do gênero Taxithelium e o estudo do material tipo, comprovou-se que o táxon, é restrito ao estado do Acre, sendo as demais ocorrências baseadas em identificações errôneas, em especial, devido à natureza altamente polimórfica de Taxithelium planum (Brid.) Mitt. Neste trabalho, apresentamos um estudo mais detalhado de T. juruense com as características que o diferenciam de T. planum. As citações equivocadas têm ocultado o verdadeiro estado de conservação desta espécie que deveria ser de espécie ameaçada (EN). Chave e ilustrações para as espécies de Taxithelium do Brasil são apresentadas.
\end{abstract}

Palavras-chave: Sematophyllaceae, Acre, endemismo, conservação

\begin{abstract}
(Taxithelium juruense (Broth.) Broth. (Pylaisiadelphaceae) an endangered Brazilian endemic, with notes on the genus Taxithelium in Brazil). Since its original description, several collections of this species were reported in different states of Brazil. During a revision of the genus, it was confirmed that the geographic range of this species is restricted to the state of Acre, all other reports being based on misidentifications due mostly to the highly polymorphic nature of Taxithelium planum (Brid.) Mitt. Here, we present a more detailed study of T. juruense with characters that will help to distinguish it from T. planum. The misidentifications have obscured the real conservation status of this species, which should be endangered (EN). Key and illustrations of the Brazilian species of Taxithelium are provided.
\end{abstract}

Key words: Sematophyllaceae, Acre, endemism, conservation

\section{Introduction}

Taxithelium Mitt. is probably one of the most widespread moss genera in the Tropics. The genus is best represented between $30^{\circ} \mathrm{N}$ and $20^{\circ} \mathrm{S}$, with most species occurring in Southeast Asia, especially the Malesian region (Damanhuri \& Longton 1996; Ramsay et al. 2002). In the Neotropics it is represented by six species being T. planum (Brid.) Mitt. by far the most common species (Damanhuri \& Longton 1996; Câmara 2011).

Taxithelium was first recognized by Spruce (1867), but the name was only later validly published by Mitten (1869) in the tribe Sematophylleae. Brotherus (1925) placed the genus in the family Sematophyllaceae, and many taxonomists have subsequently followed this treatment
(Vitt 1984; Buck \& Vitt 1986; Tan \& But 1997; Buck \& Goffinet 2000; Ramsay et al. 2002). However, Taxithelium lacks the collenchymatous exothecial cells, long rostrate operculum, and inflated alar cells that are otherwise diagnostic for the Sematophyllaceae. Recent molecular studies (Buck et al. 2000; Tsubota et al. 2001a,b) show that the Sematophyllaceae sensu latu includes two sister clades: the core sematophyllaceous taxa and the so-called "the Brotherella lineage." Based on these results, Goffinet \& Buck (2004) described the new family Pylaisiadelphaceae for the "Brotherella lineage." Although this group lacks an obvious morphological synapomorphy, Goffinet \& Buck (2004) are followed here and Taxithelium is included in the Pylaisiadelphaceae.

\footnotetext{
1 Universidade de Brasília, Departamento de Botânica, Campus Darcy Ribeiro, Brasilia, DF, Brazil

2 Author for correspondence: pcamara@unb.br
} 
The genus has been defined by the presence of multiple papillae disposed in series on the lumina of leaf cells (hence, Tax- "taso" = arranged and thelion = nipple), but there are some species in the Old World that have lost the papillae during evolution (Câmara \& Kellogg 2010). Other characters that are useful in recognizing the genus in the New World are the complanate branches with leaves having an alar region with cells not nearly as well differentiated as in most Sematophyllaceae sensu latu. The genus has recently being revised worldwide and recircumscribed with two subgenera and twenty species (Câmara 2011).

In Brazil only three species of Taxithelium occur ( $T$. juruense Broth. (Broth.), T. planum and T. pluripunctatum (Renauld \& Cardot) W. R. Buck). Among these species, a remarkable one is T. juruense. Described originally by Brotherus (1906) as Trichosteleum juruense Broth., it was later transferred to Taxithelium (Brotherus 1908).

The Brazilian species of Taxithelium were treated by Buck (1985) when he revised the genus for Brazil. He provided keys, maps, illustrations and descriptions. As expected since then, many other records have been cited elsewhere in Brazil, giving the impression that T. juruense has a wider distribution with many disjunctions. This was most likely due to misidentifications and caused much confusion. This may also lead to a wrong assessment of its conservation status.

In order to help solve this problem, after studying the type material and virtually all the Taxithelium collections known from Brazil, we were able to determine a more precise geographical range as well as provide a description of morphological traits that would enable its differentiation from other species within the genus, thus helping to avoid superfluous records and to know better its conservation status.

\section{Material and methods}

This study is a consequence of a worldwide revisionary monograph for the genus and is based on the investigation of loans totaling 6200 specimens from 30 herbaria (B, BM, BR, CANB, DUKE, E, FH, G, H, INPA, JE, L, M, MG, MICH, MO, NICH, NY, NSW, PC, PHS, S, SING, SINU, SP, TSN, UB, UPS, US, W), including types for all Taxithelium species (see Câmara 2011 for more details on types). Specimens were also studied during our visits to herbaria RB, UFP, HUEFS, CEN, IBGE and HEPH. Specimens were re-hydrated in boiling water and then mounted in Hoyer's solution (Anderson 1954). All observations and measurements were made on mounted material.

\section{Results and discussion}

\section{Taxonomic treatment}

Taxithelium juruense (Broth.) Broth. Die Natürlichen Pflanzenfamilien I(3): 1090. 1908. Trichosteleum juruense
Broth. Hedwigia 45: 285. 1906. Type- Rio Juruá, Juruá Miry, Ule 2295 (holotype: H!, isotype: NY!). Figure 1C.

Plants large, forming dull green mats. Stems creeping, short-ascending branched. Stem and branch leaves slightly differentiated; stem leaves larger and longer, erect-spreading, concave, $0.90-1.00 \times 0.25-0.35 \mathrm{~mm}$, ovate or lanceolate, margins entire, slightly revolute; apex entire, acuminate; laminal cells linear, $40-50 \times 2-3 \mu \mathrm{m}$, pluripapillose, thickwalled, basal cells smooth; costae short and double or absent; alar cells poorly differentiated, consisting of 2 rows, not inflated, not colored. Rhizoids evenly distributed along the stem. Perichaetial leaves $1.65-1.85 \times 0.30-0.40 \mathrm{~mm}$, lanceolate, margins entire at base and slightly serrulate at apex; apex long-acuminate; laminal cells linear, 50-65 × ca. $2 \mu \mathrm{m}$, thick-walled, smooth or paucipapillose at apex; costae absent; alar cells poorly differentiated with 1 row, not inflated. Setae ca. $0.8 \mathrm{~cm}$ long. Capsules erect, asymmetric, ovoid, $0.6-0.8 \mathrm{~mm}$ long, constricted below mouth; exothecial cells subquadrate, not collenchymatous. Operculum short, conic or obliquely conic-rostrate, ca. $0.3 \mathrm{~mm}$ long. Spores not seen.

Specimens examined: BRAZIL. Acre: Jurua-miry, Ule 2307 (H); Acre, Mâncio Lima, Rio Moa, 27 apr 1971, Prance 12541 (NY). Those specimens plus the type, are the only true T. juruense known to us.

Taxithelium juruense is endemic to Brazil and grows as an epiphyte on twigs in lowland forests. It is only known to occur in the state of Acre. After looking at virtually all plants named as T. juruense in the world, the authors concluded that the many citations from elsewhere in Brazil are misidentifications, mostly of T. planum, which is a highly variable species with many ecological variations. Buck (1985) treated this species and provided keys and illustrations.

Taxithelium juruense can be differentiated from $T$. planum by its smooth perichaetial leaves. Also the stem and branch leaves in T. juruense have revolute margins and a very poorly developed alar region (figure 1 and figure 2). Another useful character is the presence of papillae on the uppermost apex cells, while in T. planum those are usually absent.

It has also been confused with Hypnella pallescens (Hook.) A. Jaeger, even though both are pluripapillose. Hypnella (Pilotrichaceae) is a very distinct genus (in fact, it belongs to another order-Hookeriales), due to the presence of double costae with papillae that are sometimes bifurcated, which is unknown in Taxithelium (Câmara \& Kellog 2010).

We believe that all material from foreign herbaria formerly misidentified have been annotated; the same is true for Brazilian herbaria UB, SP, HUEFS, INPA, MG.

Conservation status: Taxithelium juruense is endemic to Brazil and is known to occur only in two localities in Acre state: on the Jurua-Miry and Moa rivers. The first collections were 


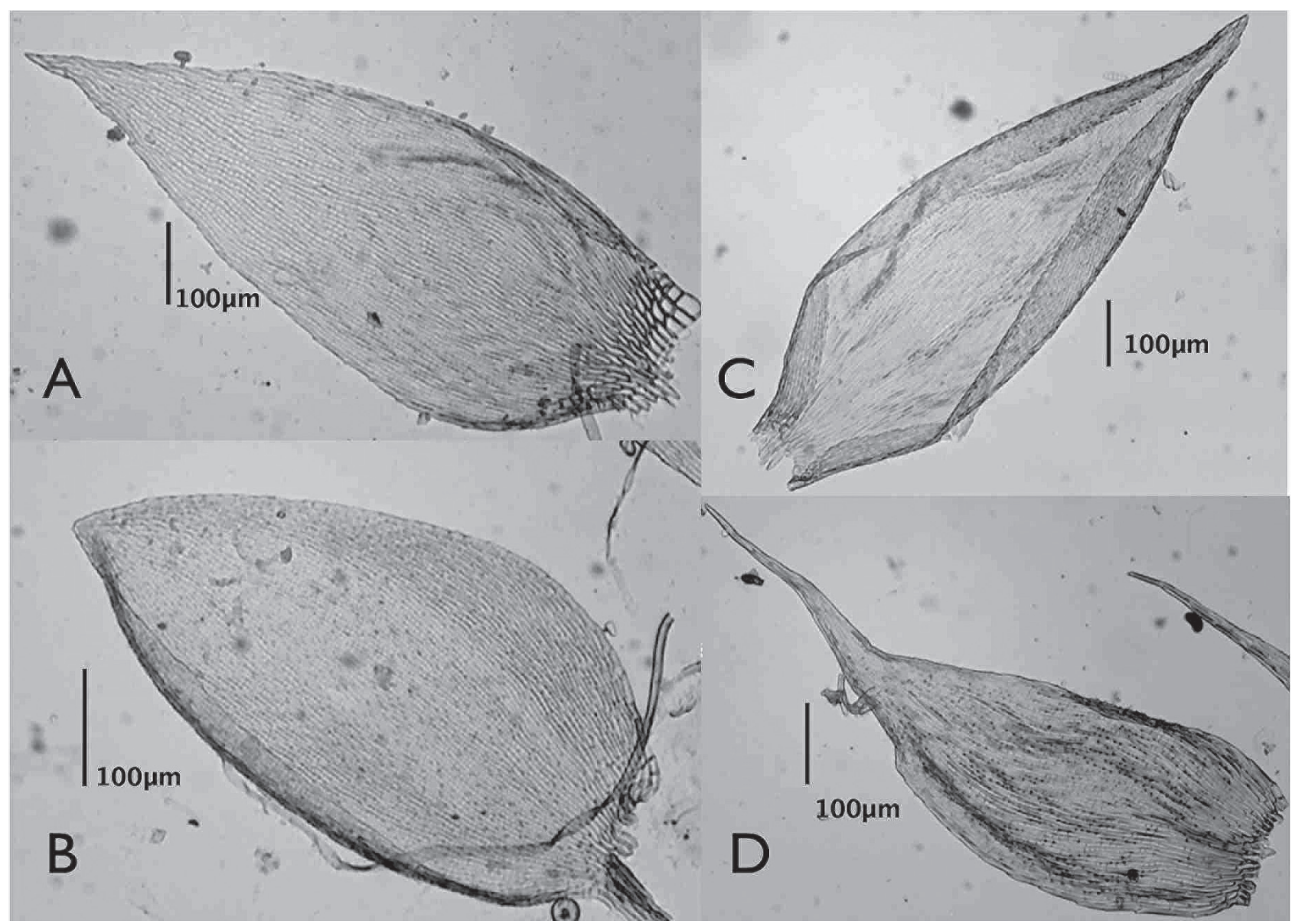

Figure 1. Differences in leaf shape from the three species of Taxithelium from Brazil. A-B-T. planum; C-T. juruense; D-T. pluripuncatum.

made by the naturalist Ernest Ule 2295, $2307(\mathrm{H})$, between 1901 and 1902 on the Juruá Mirim River (originally spelled Juruá-Miry). Even though the type collection examined at herbarium $\mathrm{H}$ does not contain exact data on locality, duplicates from that expedition deposited at NY clarify that it happened in the municipality of Porto Valter. Later, after 60 years, Prance 12541 (NY) recollected the species by Moa River, municipality of Mâncio Lima, about $50 \mathrm{~km}$ from Porto Valter.

Taxithelium juruense has a very restricted range (with only two localities known), and it has not been collected again in over 40 years, even with collecting projects happening in the region, such as "Florística e Botânica econômica do Acre, Brasil" (Floristics and economic botany in Acre, Brazil). This project started in 1992 in collaboration with the New York Botanical Garden and Universidade Federal do Acre and has recently made collecting trips in Juruá Mirim and Moa rivers, but no T. juruense was found. Even so, according to the IUCN $(2001,2010)$ criteria, $T$. juruense would fit into the category Data Deficient (DD).

However, due to bryophyte particularities, Hallingbäck et al. (1998) have published "Guidelines for applications of the revised IUCN threat categories". Following these guidelines T. juruense should be considered as an endangered species
(EN), according to criteria "B" (restricted area of occupancy, recently recorded in one $10 \mathrm{~km} \times 10 \mathrm{~km}$ square and found up to two localities/severely fragmented and in decline).

We adopt this more appropriate approach, since this species may well be extinct from nature or have an even more restricted area of occupancy.

Even though there is a red list for the threatened flora in Brazil (http://www.biodiversitas.org.br/floraBr/), Taxithelium juruense is not listed there. We strongly recommend its inclusion. It would be the first threatened moss in the Amazon basin.

Other species of Taxithelium from Brazil: As stated above there are two other species of Taxithelium occurring in Brazil, neither one is threatened so far; they are T. planum (Figure 1A, B) and T. pluripunctatum (Figure 1D). These species belong in two different subgenera. The report of T. portoricense R.S. Williams for the Brazilian Amazon by Lisboa \& Ilkiu-Borges (1997) was based on a misidentification of T. pluripunctatum, (the paper itself shows a picture of T. pluripunctatum). Taxithelium portoricense is endemic to the Caribbean islands (Câmara 2011).

Taxithelium planum is a very common species known to occur widely from southern North America to South 


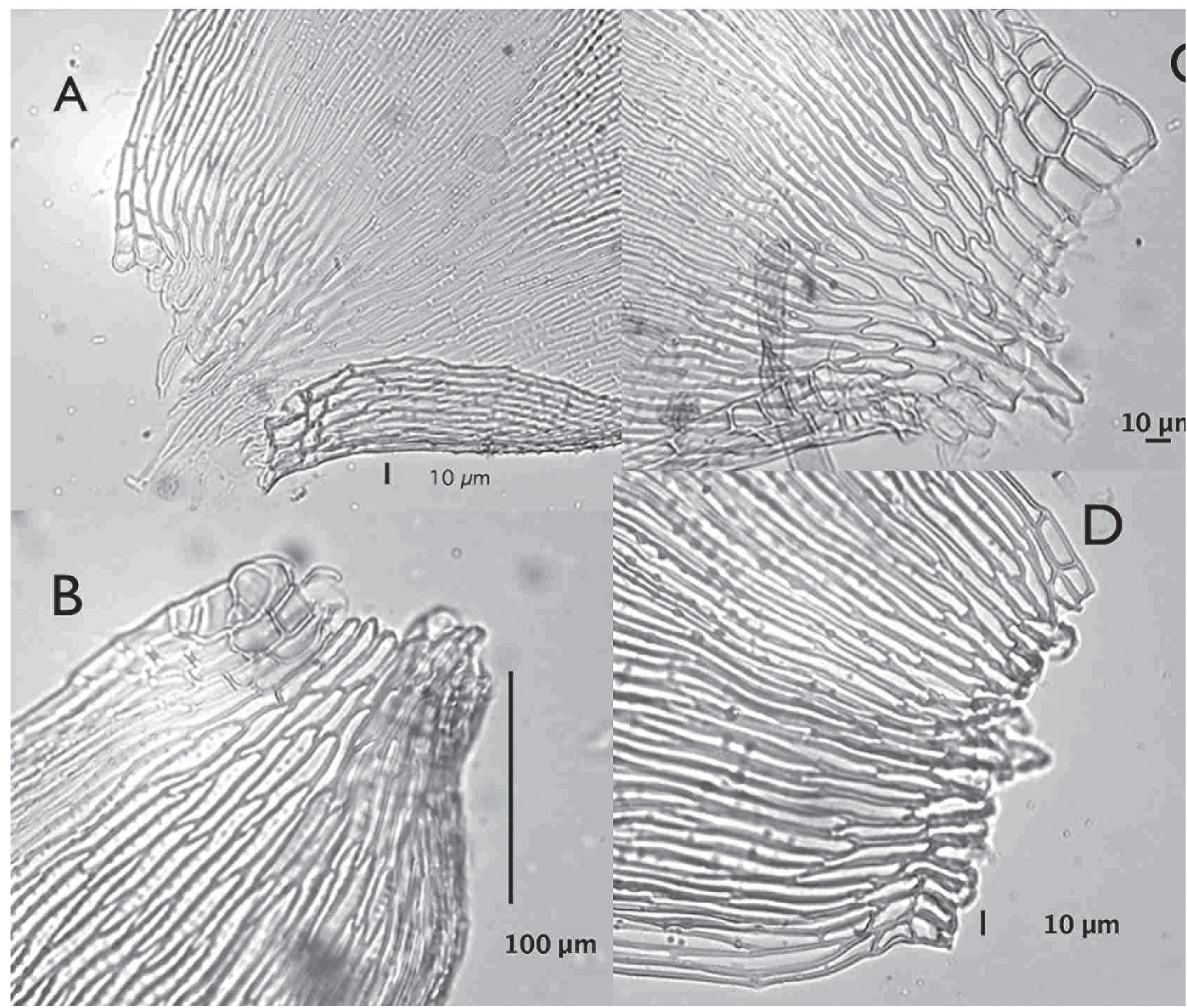

Figure 2. Differences among the alar region in the three species of Taxithelium from Brazil. A-T. juruense, B and C-T. planum; D-T. pluripuncatum.

Brazil and also Africa. It has been misreported from Asia because it resembles the Asian species Taxithelium nepalense (Schwägr.) Broth. As stated above it is a highly variable species; leaf shape variation can be seen in Fig.1A, B. Another useful character is its somewhat developed alar region when compared to the other two (Figure 2).

In Brazil Taxithelium planum is distributed widely in the states of AC, AL, AM, AP, BA, DF, ES, GO, MA, MG, MS, MT, $\mathrm{PA}, \mathrm{PB}, \mathrm{PE}, \mathrm{PR}, \mathrm{RJ}, \mathrm{RO}, \mathrm{RR}, \mathrm{SC}, \mathrm{SP}, \mathrm{TO}$. It ranges from 0-1090 m.
Taxithelium planum is differentiated from $T$. pluripunctatum by the presence of foliose pseudoparaphyllia and ovate complanate leaves. It also has papillae of a baggy shape (Câmara \& Kellogg 2010) whereas T. pluripunctatum has conical papillae. Taxithelium pluripunctatum is a strictly Neotropical species known to occur mostly from Central America to northern Brazil in the states of AM, $\mathrm{BA}, \mathrm{PA}, \mathrm{PE}, \mathrm{RR}$. It is a lowland plant known to occur in Brazil from 0 to $200 \mathrm{~m}$.

Key to the Brazilian species of Taxithelium

1. Plant with filamentous pseudoparaphyllia; leaves lanceolate, slightly falcate. T. pluripunctatum

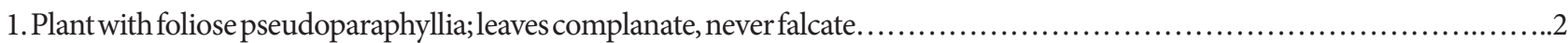

2. Plants with involute margins; presence of papillae at the very leaf apex; perichaetial leaves smooth.................... juruense

2. Plants margins plane; absence of papillae at the very leaf apex; perichaetial leaves papillose.

T. planum 


\section{Acknowledgements}

We are thankful to Toby Kellogg, Peter Stevens, Bob Magill, Bill Buck, Bruce Allen, and John Atwood. We also thank the curators of cited herbaria. This study was partially funded by CAPES, Brazilian government and the Missouri Botanical Garden. We also thank Renato Gama Dias Neto for helping with the figures.

\section{References}

Anderson, L.E. 1954. Hoyer's solution as a rapid permanent mounting medium for bryologists. The Bryologist 57: 242-244.

Brotherus, V.F. 1906. Musci amazonici et subandini Uleani. Hedwigia 45: 260-288.

Brotherus, V.F. 1908. Bryales, in part. Die Natürlichen Pflanzenfamilien. I(3): 1057-1152.

Brotherus, V.F. 1925. Musci (Laubmoose). 2. Hälfte. In: A. Engler. Die Natürlichen Pflanzenfamilien. 2 ed. Leipzig, W. Engelmann.

Buck, W.R. 1985. A review of Taxithelium (Sematophyllaceae) in Brazil. Acta Amazonica Suppl. 15(1-2): 43-53.

Buck, W.R. \& Vitt, D.H. 1986. Suggestions for a new familial classification of pleurocarpous mosses. Taxon 35: 21-60.

Buck, W.R. \& Goffinet, B. 2000. Morphology and classification of mosses. Pp. 225-237. In: Shaw, A.J. \& Goffinet, B. (Eds.). Bryophyte Biology. Cambridge, Cambridge University Press.

Buck, W.R.; Goffinet, B. \& Shaw, A.J. 2000. Novel relationships in pleurocarpous mosses as revealed by cpDNA sequences. The Bryologist 103: $774-789$.

Câmara, P.E.A.S. \& Kellogg, E.A. 2010. Morphology and development of leaf papillae in Sematophyllaceae. The Bryologist 113: 22-33.

Câmara, P.E.A.S. 2011. A Re-circumscription of the moss genus Taxithelium (Pylaisiadelphaceae) with a taxonomic revision of subgenus Vernieri. Systematic Botany 36(1): 1-15.

Damanhuri, A. \& Longton, R.E. 1996. Towards a revision of the moss genus Taxithelium (Sematophyllaceae). Annales Instituto de Biologia. Universidad Autónoma de Mexico, Series Botanica 67: 35-58.
Goffinet, B. \& Buck, W.R. 2004. Systematics of the Bryophyta (mosses): from molecules to a revised classification. Monographs in Systematic Botany from the Missouri Botanical Garden 98: 205-239.

Hallingbäck, T.; Hodgetts, N.; Raeymaekers, G.; Schumacker, R.; Sérgio, C.; Söderström, L.; Stewart, N. \& Vána, J. 1998. Guidelines for application of the revised IUCN threat categories to bryophytes. Lindbergia 23: 6-12.

IUCN. 2001. IUCN Red List Categories and Criteria: Version 3.1. IUCN Species Survival Commission. IUCN, Gland, Switzerland and Cambridge, UK. ii +30 pp.

IUCN 2010. IUCN Standards and Petitions Subcommittee. 2010 Guidelines for Using the IUCN Red List Categories and Criteria. Version 8.1. Prepared by the Standards and Petitions Subcommittee in March 2010. Downloadable from http://intranet.iucn.org/webfiles/ doc/SSC/RedList/RedListGuidelines.pdf.

Lisboa, R.C.L. \& Ilkiu-Borges, A.L. 1997. Novas ocorrências de Bryophyta (musgos) para o Estado do Pará, Brasil. Acta Amazonica 27: 81-102.

Mitten, W. 1869. Musci Austro Americani. Journal of the Linnean Society Botany 12: 1-659.

Ramsay, H.P.; Schofield, W.B. \& Tan, B.C. 2002. The genus Taxithelium (Bryopsida, Sematophyllaceae) in Australia. Australian Systematic Botany 15: 583-596.

Spruce, R. 1867. Catalogus Muscorum fere Omnium quos in Terris Amazonicus et Andinis, per Annos 1849-1860, legit Ricardus Spruceus. London, E. Newman.

Tan, B.C. \& But, P.Ph. 1997. A revision of post-war collections of Hong Kong Sematophyllaceae . Journal of Bryology 19: 787-798.

Tsubota, H.; Akiyama, H.; Yamaguchi, T. \& Deguchi, H. 2001a. Molecular phylogeny of the Sematophyllaceae (Hypnales, Musci) based on chloroplast rbcL sequences. The Journal of the Hattori Botanical Laboratory 90: 221-240.

Tsubota, H.; Akiyama, H.; Yamaguchi, T. \& Deguchi, H. 2001b. Molecular phylogeny of the genus Trismegistia and related genera (Sematophyllaceae, Musci) based on chloroplast rbcL sequences. Hikobia 13: 529-549.

Vitt, D.H. 1984. Classification of the Bryopsida. Pp. 696-759. In: Schuster, R.M. (Ed.) New Manual of Bryology. vol. 2. Nichinan, Hattori Botanical Laboratory. 